\title{
Status of PPR and Sero-conversion of PPR Vaccines in Goats and Sheep of Midwestern Region of Nepal
}

\author{
K. R. Pandey, ${ }^{*}$ and J. Shrestha \\ Regional Veterinary Laboratory (Midwestern Region), Birendranagar, Surkhet, Nepal \\ *Corresponding author: drpandeykr@yahoo.com
}

\begin{abstract}
Peste des petits ruminant (PPR) is a common, acute, highly contagious and infectious viral epidemic disease of small ruminants which has caused significant economic losses in Nepal. Total of 247 suspected serum samples from 13 outbreaks from 8 districts of the Midwestern region of Nepal in 2015 were confirmed by using antibody ELISA test and in case of dead animals, the tissue samples were further confirmed by using antigen ELISA test. Out of 247 serum samples, 153 (61.9\%) samples showed PPR antibody positive. The Ecozone wise distribution of PPR showed that the PPR outbreak were reported the highest in mountain followed by hills and the lowest in Terai. The highest outbreaks in mountain may be due to excessive movements of nomadic herd of sheep and goat, common pasture, low vaccine coverage in mountain whilst in hill region due to geographic difficulty and low sero-conversion of vaccine. Hence, strategic vaccination campaigns, proper biosecurity, movement control, risk analysis and early diagnosis need to be implemented for the control of PPR in the country.
\end{abstract}

Keywords: small ruminants, Peste des petits ruminant, ELISA

\section{INTRODUCTION}

Nepal is an agricultural country where $60.4 \%$ of the population is based on agriculture for their livelihood. Out of this $80 \%$ of the population have livestock farming as an integrated way. Cattle, buffalo, goat and poultry farming is the common animal species. The population of different livestock species in million is as buffalo 5.2, cattle 7.2, goats 11, sheep 0.8, pigs 1.2 and chicken 50.2. Agriculture contributes $31.23 \%$ in GDP and Livestock contributes 25.68\% in Agriculture Gross Domestic Products (MOAD, 2015). Peste des petits ruminants (PPR) is an acute highly contagious and infectious viral disease of small ruminants like sheep and goats caused by a RNA virus of family Paramyxoviridae. PPR has been reported in various parts of Asia and Africa. PPR was first reported from Ivory Coast in West Africa in 1942 whereas this disease was first reported in Nepal in Central Terai in 1995. This disease has caused significant economic losses among small ruminant farmers of Nepal through high 
morbidity and mortality pattern of the diseases. The major signs include high fever discharges from eyes, nose, mouth and severe diarrhea. The major sources of disease transmission are the discharges from eyes, nose, and mouth, and anus, close contact between infected and susceptible animals. In Nepal, PPR outbreak is associated with introduction of recently purchased animals from neighboring countries and abroad. National level PPR control program has been implemented by vaccination to prevent huge economic loss of the farmers. This present study was conducted to determine the status of PPR and sero-conversion of PPR vaccines in sheep and goats in midwestern region of Nepal.

\section{MATERIALS AND METHODS}

During the time of outbreak in midwestern region of Nepal from July 2015 to March 2016, the 247 serum samples were collected from suspected animals and tissue samples were collected from dead animals. The diagnosis was done based on history taking, clinical examination and postmortem examination. Serum samples of suspected animals were confirmed by using antibody ELISA test in Regional Veterinary Laboratory, Surkhet. Vaccination program against PPR throughout the country was conducted after outbreak and the serum samples were collected again after three weeks of vaccination. These serum samples were also tested using antibody ELISA test.

\section{RESULT AND DISCUSSION}

\section{Districtwise distribution of PPR}

PPR is a common epidemic among the small ruminant population of the country. During the study, total 247 outbreak suspected serum samples were tested for PPR, out of which $153(61.9 \%)$ serum samples were confirmed to be PPR antibody positive. During the study period PPR have been confirmed from eight districts out of 15 districts in the Mid-western region of Nepal that is Jumla, Dailekh, Jajarkot, Dolpa, Mugu, Humla, Dang and Banke (Figure 1). No outbreaks were reported in remaining seven districts namely Bardiya, Surkhet, Ruknum, Rolpa, Salyan, Pyuthan and Kalikot of mid-western region of Nepal. In the region, total of 13 outbreaks occurred which caused death of 9230 (39\%) out of 23670 infected goat and sheep. The highest number of PPR outbreak was reported in Dailekh $(n=4)$ followed in Mugu ( $n=3)$ and one each in Jumla, Jajarkot, Humla, Dolpa, Dang and Banke. The highest number of outbreaks in Dailekh might be due to high movement of goats and sheep along the road corridor and in Mugu might be due to the common large pastureland. In Nepal, PPR has been reported from 68 districts out of 75 districts in past 20 years. Only in 2015, total 71 outbreaks of PPR was reported from 26 different districts in the country. 


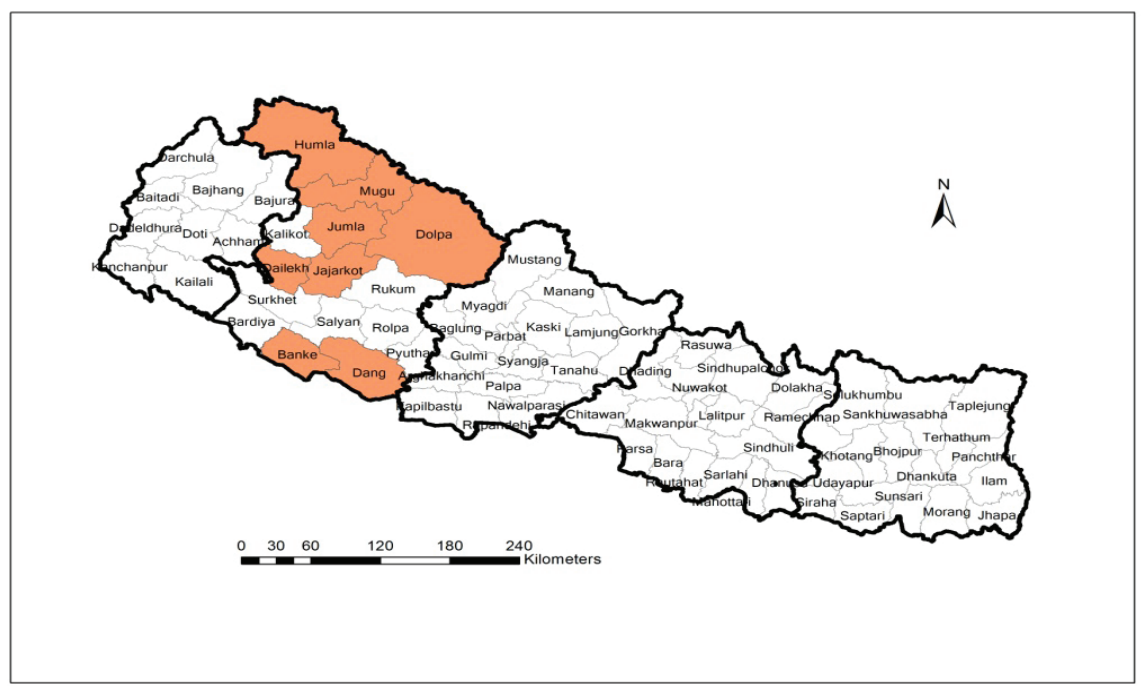

Fig. 1: PPR outbreak districts in mid-western region of Nepal

Total 1302 serum samples were collected after 3 weeks of vaccination from 11 districts of this region and tested by Antibody ELISA (Table 1).

Table 1: Sero-monitoring in different district

\begin{tabular}{|c|l|c|c|c|c|c|}
\hline S.N. & District & $\begin{array}{c}\text { Number of } \\
\text { Vaccination }\end{array}$ & $\begin{array}{c}\text { Sample } \\
\text { Tested }\end{array}$ & Positive & Negative & $\begin{array}{c}\text { Positive } \\
\text { Percentage }\end{array}$ \\
\hline 1 & Banke & 500000 & 152 & 104 & 48 & 68.4 \\
\hline 2 & Bardiya & 60000 & 120 & 81 & 39 & 67.5 \\
\hline 3 & Dang & 60000 & 92 & 81 & 11 & 88.0 \\
\hline 4 & Surkhet & 50000 & 232 & 157 & 75 & 67.7 \\
\hline 5 & Dailekh & 35000 & 136 & 78 & 58 & 57.4 \\
\hline 6 & Jajarkot & 35000 & 72 & 64 & 8 & 88.9 \\
\hline 7 & Rukum & 25000 & 44 & 26 & 18 & 59.1 \\
\hline 8 & Rolpa & 30000 & 60 & 36 & 24 & 60.0 \\
\hline 9 & Salyan & 25000 & 158 & 112 & 46 & 70.9 \\
\hline 10 & Pyuthan & 35000 & 126 & 99 & 27 & 78.6 \\
\hline 11 & Jumla & 25000 & 110 & 82 & 28 & 74.5 \\
\hline & Total & 430000 & 1302 & 920 & 382 & 70.7 \\
\hline
\end{tabular}




\section{Ecozone wise distribution of PPR}

The Ecozone wise distribution of PPR in Midwestern region is shown in figure 2. Out of 13 outbreaks recorded in midwestern region, six outbreaks were reported from mountain region, five were reported in hills and two were in Terai regions. The highest outbreaks in mountain may be due to excessive movements of nomadic herd of sheep and goat, common pasture, low vaccine coverage in mountain whilst in hill region due to geographic difficulty and low sero-conversion of vaccine.

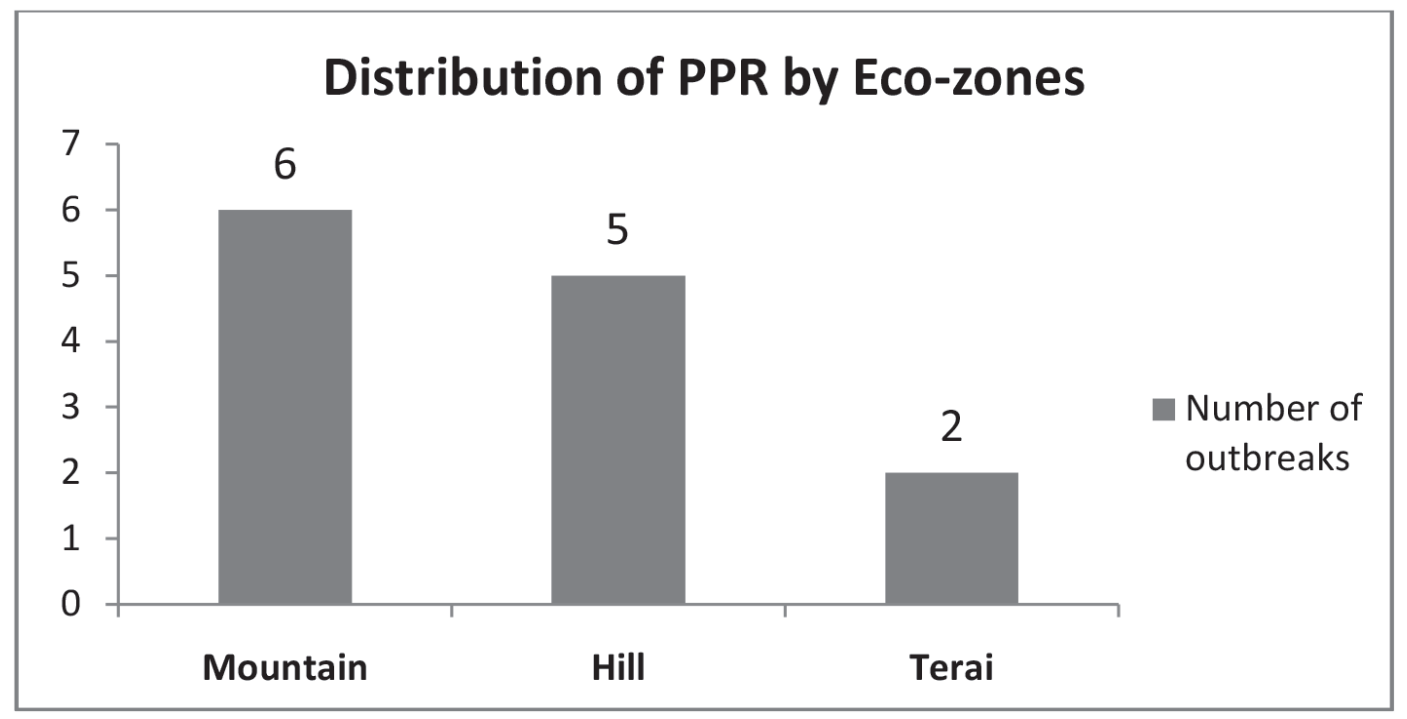

Fig. 2: The Ecozone wise distribution of PPR

\section{Vaccination coverage and Seroconversion}

The total population of goats in the country is 10.3 million and sheep is 0.8 million (MoAD 2015). Within the country, the mid-western region is a potential hub for goat and sheep farming. This region constitutes $25 \%$ (2.6 million) out of national goat population (10.3 million) and $45 \%$ ( 0.36 million) of total sheep population (0.8 million) of the country (RDLS, 2015). In order to control this disease, National PPR Control Program through vaccination has been implemented. The national vaccination coverage against PPR during 2015 was recorded as $22 \%$ (VEC, 2015) whereas the vaccination coverage in this region is $14.3 \%$ (RVL, 2015). The national seroconversion of vaccine was found very low which $57.2 \%$ (CVL, 2015) is whereas the average seroconversion in this region was found as $70.7 \%$.

The trend of sero-conversion of PPR vaccine in different districts in this region is shown in figure 3 . The reasons behind low sero-conversion could be due to condition 
of animals, vaccination skills of technicians, vaccine storage, transportation, sampling error and sincerity of farmers and technicians.

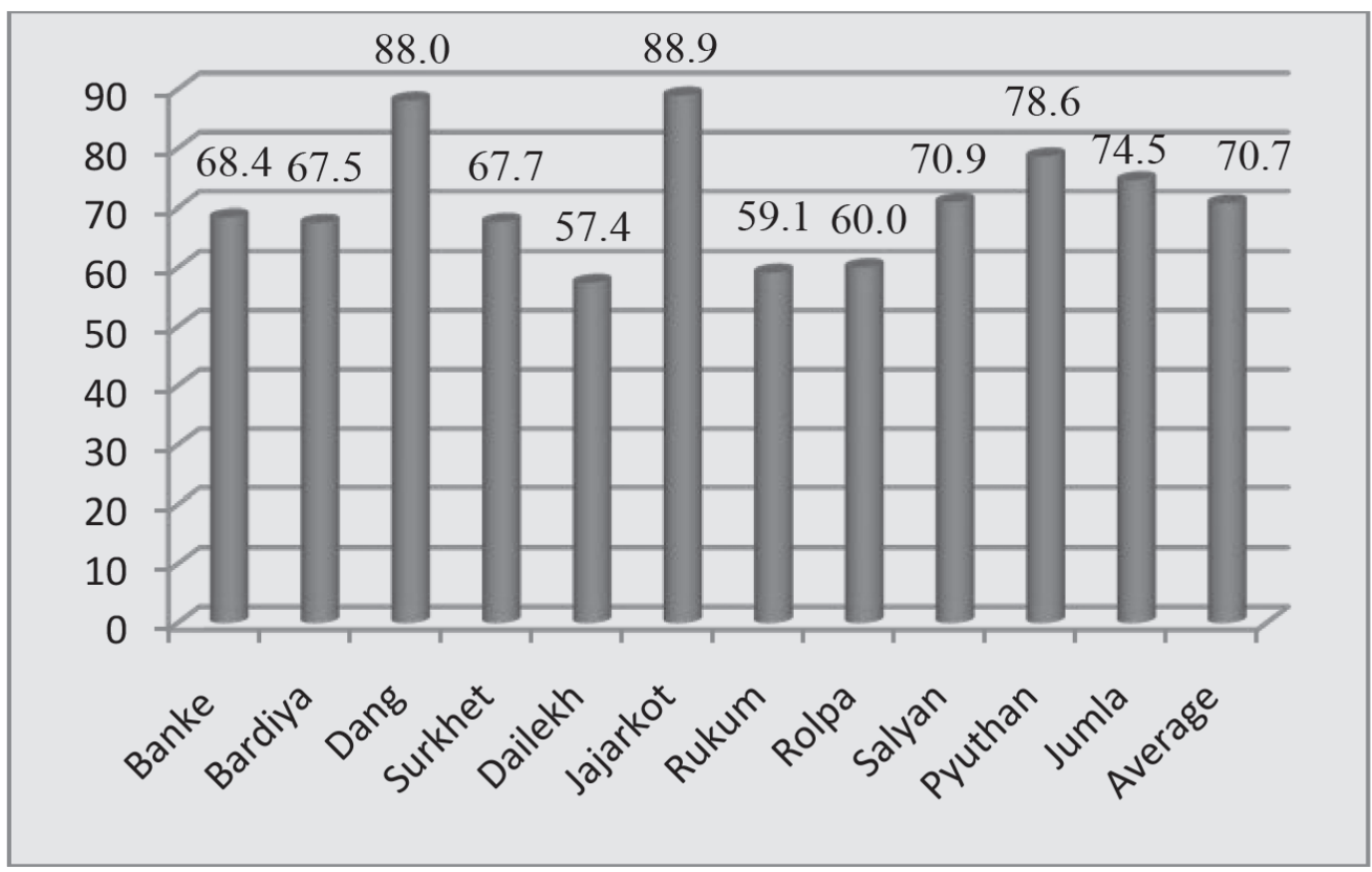

Fig. 3: The trend of sero-conversion of PPR vaccine in different districts of Midwestern region

\section{CONCLUSION}

PPR is a common problem among sheep and goat population of the country. There were total of 13 outbreaks from eight districts confirmed by using antibody ELISA test. In these districts, 39\% (9230) of deaths were confirmed due to PPR out of 23670 infected sheep and goats which causes huge economic losses to the farmers. High number of outbreaks in mountain followed by hills may be due to excessive movements of nomadic herd of sheep and goats as per seasonal variation, common pasture, low vaccine coverage in mountain and hill region due to geographic difficulty and low sero-conversion of vaccine. Strategic vaccination campaigns against PPR, proper biosecurity, movement control, early diagnosis are the tools to control the PPR. The use of good quality vaccines in healthy animals with proper identification and without sampling error should be done for the best sero-conversion. 
Nepalese Vet. J. 35:41-46

\section{REFERENCES}

CVL 2015, Annual Technical Report 2014/015.

MOAD 2015, Selected indicators of Nepalese Agriculture and Population, Nepal.

RDLS 2015, Annual Progress Report, Mid-western region, Birendranagar, Nepal

RVL, 2015 Annual Technical Report 2014/015.

VEC 2015, Annual Epidemiological Bulletin January -December, volume 11, number 3 . 